\title{
Peran Relawan Demokrasi dalam Sosialisasi Pemilihan Umum Serentak 2019 pada Pemilih Lanjut Usia di Kabupaten Solok
}

\author{
Rosalina, Al Rafni \\ Program Studi Pendidikan Pancasila dan Kewarganegaraan \\ Universitas Negeri Padang \\ E-mail: rrosalina27@gmail.com
}

\section{ABSTRAK}

Pasca reformasi tingkat partisipasi pemilih pada pemilihan umum (Pemilu) cenderung menurun. Hal tersebut memicu Komisi Pemilihan Umum (KPU) membentuk program relawan demokrasi (Relasi) di setiap KPUD yang ada di masing-masing daerah. Relasi sebagai perpanjangan tangan KPU untuk memberikan sosialisasi tentang pemilu memiliki tujuan utama agar partisipasi pemilih meningkat. Penelitian ini menggunakan metode kualitatif dengan pendekatan deskriptif. Pengumpulkan data dilakukan dengan cara wawancara dan studi dokumentasi. Tujuan penelitian ini adalah untuk mendeskripsikan peran relawan demokrasi dalam sosialisasi pemilu serentak 2019 pada pemilih lanjut usia di Kabupaten Solok. Secara umum, relawan demokrasi memiliki peran sebagai mitra KPU dalam memberikan sosialisasi tentang pemilu serentak 2019 dan sebagai agen pendidikan pemilih. Adapun kendala yang ditemui oleh relawan demokrasi dalam sosialisasi pemilu serentak 2019 pada pemilih lanjut usia di Kabupaten Solok adalah kendala yang berasal dari faktor internal dan eksternal. Upaya yang dilakukan oleh relawan demokrasi untuk mengatasi kendala yang berasal dari internal dan eksternal tersebut adalah saling bekerjasama dengan basis-basis lain, menyampaikan informasi tentang pemilu dengan berulang-ulang, dan secara individu.

Kata Kunci: relawan demokrasi, pemilu serentak 2019, pemilih lansia

\section{ABSTRACT}

Post-reformation the level of voter participation in general elections (Elections) tends to decrease. This triggered the General Election Commission (KPU) to form a volunteer democracy program (Relation) in each KPUD in each region. Relationships as an extension of the KPU to provide information on elections have the main objective of increasing voter participation. This research uses a qualitative method with a descriptive approach. Data collection is done by interview and documentation study. The purpose of this study is to describe the role of volunteer democracy in the 2019 simultaneous election socialization among elderly voters in Solok Regency. In general, democracy volunteers have a role as KPU partners in providing socialization about the 2019 concurrent elections and as voter education agents. The obstacles encountered by democratic volunteers in the simultaneous election 
socialization of 2019 to elderly voters in Solok Regency are obstacles that come from internal and external factors. Efforts made by democratic volunteers to overcome these internal and external obstacles are mutual cooperation with other bases, conveying information about elections repeatedly, and individually.

\section{Keywords : volunteer democracy, 2019 concurrent elections, elderly voters}

This work is licensed under the Creative Commons Attribution-ShareAlike 4.0 International License. (C)2019 by author.

\section{PENDAHULUAN}

Program relawan demokrasi adalah gerakan sosial yang dimaksudkan untuk meningkatkan partisipasi dan kualitas pemilih dalam menggunkan hak pilih. Relawan demokrasi menjadi mitra KPU dalam menjalankan agenda sosialisasi dan pendidikan pemilih berbasis kabupaten/kota. Menurut Rafni (2017), mengatakan bahwa :"The program is further aimed at expanding public political participation and improving public faith toward the democratic process. It also involves the public role as democratic pioneers in their own community with the expectation that the political literacy can be improved when the role, functions, and performance of the volunteers can be optimally performed".

Program relawan demokrasi ditujukan untuk memperluas partisipasi politik masyarakat dan meningkatkan kepercayaan masyarakat terhadap proses demokrasi serta melibatkan peran masyarakat sebagai pelopor demokrasi di komunitasnya sendiri dengan harapan literasi dapat ditingkatkan ketika peran, fungsi dan kinerja relaan dapat dilakukan secara optimal. Pada pemilu 2019 program ini kembali dibentuk sesuai peraturan KPU RI Nomor: 32/PP.08SD/06/KPU/I/2019 tentang Pembentukan Relawan Demokrasi
Pemilu Serentak 2019. Sementara dalam lampiran surat KPU RI Nomor : 32/PP.08-SD/06/KPU/I/ 2019

menjelaskan tugas Relawan Demokrasi sebagai subjek yang akan melakukan sosialisasi dan pendidikan kepada pemilih.

$\begin{array}{crr}\text { Pembentukan } & \text { Relawan } \\ \text { Demokrasi } & \text { pada } & \text { setiap }\end{array}$
Kabupaten/Kota dibatasi hanya 55 orang dengan tujuan meningkatkan partisipasi pemilih dan menurunkan angka suara tidak sah. Relawan Demokrasi yang terdiri dari 55 orang tersebut melibatkan kelompok masyarakat yang berasal dari 11 basis pemilih strategis yaitu basis keluarga, pemilih pemula, pemilih muda, pemilih perempuan, penyandang disabilitas, pemilih berkebutuhan khusus, kaum marginal, komunitas, keagamaan, warga internet dan basis relawan demokrasi. Pelopor-pelopor demokrasi akan dibentuk di setiap basis yang kemudian menjadi penyuluh pada setiap komunitasnya. Segmentasi berdasarkan basis pemilih dilakukan dengan kesadaran bahwa tidak semua lapisan masyarakat mampu dijangkau oleh program KPU. Selain itu segmentasi tersebut adalah strategis baik dari sisi kuantitas maupun pengaruhnya dalam dinamika sosial-politik berbangsa dan bernegara.

Menurut Subakti dalam Purbolaksono (2019) terdapat dua 
variabel penting yang mempengaruhi tinggi rendahnya partisipasi politik. Pertama, tingkat kesadaran politik yaitu kesadaran hak dan kewajiban warga negara. Kedua, menyangkut penilaian warga negara terhadap kebijakan pemerintah dan pelaksanaan pemerintah. Mengacu pada variabel pertama, meningkatnya partisipasi pemilih pada pemilu serentak 2019 menandakan semakin tingginya kesadaran politik masyarakat tentang hak dan kewajibannya. Hak dan kewajiban masyarakat dalam bidang politik salah satunya adalah ikut berpartisipasi dalam pemilu. Sementara jika mengacu pada variabel dua tentang penilaian pemilih terhadap kinerja pemerintahan diperngaruhi oleh adanya pembelaan pendukung kedua calon presiden dan wakil presiden. Besarnya animo kedua pendukung akhirnya meningkatkan jumlah partisipasi pemilih dalam pemilu serentak 2019. Kendati demikian meningkatnya partisipasi pemilih tidak terlepas dari peran serta KPU dalam mensosialisasikan pemilu serentak 2019 melalui Relawan Demokrasi.

Terdapat beberapa penelitian yang telah mengkaji tentang relawan demokrasi yaitu penelitian Harianti dan Rafni (2018) yang berjudul Implementasi kebijakan program relawan demokrasi oleh KPU Kota Padang pada pilkada 2018. Kebijakan program relawan demokrasi di Kota Padang dinilai berhasil. Hal Ini dapat dilihat dari peningkatan partisipasi pemilih. Pada pilkada 2013 tingkat partisipasi pemilih hanya sekitar $52 \%$, kemudian setelah dibentuknya relawan demokrasi, tingkat partisipasi masyarakat naik menjadi $12 \%$ dengan tingkat partispasi $64 \%$ pada pilkada 2018. Hal tersebut dapat secara ilmiah diteliti tentang bagaimana implementasi program relawan demokrasi oleh KPU pada pilkada Kota Padang 2018 jika dilihat dari faktor-faktor keberhasilannya. Hasil penelitian didapat bahwa implementasi kebijakan program relawan demokrasi di KPU pada pilkada Kota Padang terdapat faktor keberhasilan seperti komunikasi yang sudah efektif, sumber daya relawan demokrasi memiliki standar operasional (SOP) dan tugas pokok yang jelas.

Kemudian penelitian Febriantanto (2018) yang berjudul implementasi program relawan demokrasi pada pemilu 2014 di KPU Kota Yogyakarta. Kebijakan program relawan demokrasi di Kota Yogyakarta dinilai berhasil, jumlah partisipasi pemilih di Kota Yogyakarta pada pemilu legislatif 2014 menunjukkan peningkatan dari pemilu legislatif 2009. Partisipasi pemilih pada pemilu legislatif mencapai $75,88 \%$ atau meningkat cukup banyak dibanding pemilu legislatif 2009 yaitu sekitar $68 \%$. Peningkatan partisipasi pemilih tersebut merupakan angka partisipasi tertinggi sepanjang pemilu legislatif di Kota Yogyakarta. Hal tersebut dapat secara ilmiah diteliti tentang bagaimana implementasi program relawan demokrasi oleh KPU Kota Yogyakarta jika dilihat dari faktorfaktor keberhasilannya. Hasil penelitian didapat faktor keberhasilan seperti komunikasi yang diterapkan cukup jelas, kepemilikan sumber daya dinilai cukup memadai, disposisi yang sudah optimal, dan struktur birokrasi sudah mencerminkan efisiensi. 
Volume 1 No. 42018

Berikutnya penelitian Sucipto (2019) menyatakan bahwa peran relawan demokrasi di Kabupaten Banggai Laut dapat dikatakan berhasil karena tingkat partisipasi pemilih dalam pemilihan umum srentak 2019 di Kabupaten Banggai Laut mencapai 84,74\%. Dalam pelaksanaannya pemilihan umum salah satu komponen penting yang harus mendapat perhatian serius adalah tingkat partisipasi masyarakat yang mempunyai hak pilih dalam menggunakan hak pilihnya karena semakin tinggi tingkat partisipasi masyarakat maka kualitas pemilu akan semakin baik dan sebaliknya jika tingkat partisipasi masyarakat rendah maka hasil pemilu bisa dikatakan kurang mendapatkan ligitimasi dari masyarakat. Oleh sebab itu dibentuknya relawan demokrasi oleh KPU merupakan upaya meningkatkan partisipasi masyarakat dalam memberikan suaranya dalam pemilihan umum.

Dari penelitian terdahulu diatas dapat disimpulkan bahwa program relawan demokrasi di nilasi berhasil. Sejak diadakannya program relawan demokrasi untuk sosialisasi pemilu kepada masyarakat terjadi peningkatan jumlah partisipasi pemilih pada saat pemilu. Hal tersebut dapat dilihat dari partisipasi pemilih pemilu 2014 berada diangka 75,2\% dan pada pemilu serentak 2019 partisipasi pemilih mencapai $81 \%$. Partisipasi pemilih pada pemilu serentak 2019 berhasil melampaui target nasional dari KPU yang menargetkan partisipasi pemilih diangka 75,5\%. Keberhasilan dari program relawan demokrasi tersebut tidak terlepas dari beberapa faktor diantaranya komunikasi yang sudah efektif, sumber daya relawan demokrasi memiliki standar operasi (SOP), disposisi yang sudah optimal, struktur birokrasi sudah mencerminkan efisiensi dan tugas pokok yang jelas. Secara keseluruhan relawan demokrasi sudah bekerja sesuai dengan fungsinya sebagai agen pendidikan politik dan agen pendidikan pemilu. Dengan mekanisme kerja yang digunakan berbeda-beda disesuaikan dengan situasi dan kondisi yang dibutuhkan.

Didalam penelitian terdahulu hanya membahas tentang sosialisasi kepada basis pemula dan basis disabilitas. Sedangkan pada penelitian ini, peneliti lebih menfokuskan pada peran relawan demokrasi dalam mensosialisasikan pemilihan umum serentak 2019 pada pemilih lanjut usia di Kabupaten Solok. Urgensi dari penelitian ini adalah karena partisipasi pemilih di Kabupaten Solok masih terbilang rendah, dari 281.902 DPT (daftar pemilih tetap) di Kabupaten Solok tingkat partisipasi pemilihnya hanya $74,42 \%$. Persentase tersebut belum mencapai terget nasional yang telah ditentukan KPU nasional yaitu $77,5 \%$. Kemudian jumlah lanjut usia di Kabupaten Solok tergolong dalam jumlah yang banyak. Menurut Peraturan Menteri Kesehatan Republik Indonesia No. 25 Tahun 2016 Tentang Rencana Aksi Nasional Kesehatan Lanjut Usia Tahun 2016-2019. Lanjut usia adalah seseorang yang telah mencapai usia 60 (enam puluh) tahun keatas. Berdasarkan data Badan Pusat Statistik 2018 di Kabupaten Solok terdapat 36.199 jumlah lansia yang berusia 60 tahun keatas.

Kemudian masih kurang maksimal sosialisasi pemilu serentak 2019 kepada pemilih lanjut usia di 
Kabupaten Solok. Relawan demokrasi untuk basis pemilih lansia itu sendiri sebenarnya tidak ada namun dalam pelaksanaan sosialisasi relawan demokrasi juga melakukan sosialisai kepada lansia. Sosialisasi tentang pemilu serentak 2019 terhadap lansia ini dilakukan relawan demokrasi di Kabupaten Solok melalui basis relasi, basis keluarga, basis perempuan, basis khusus dan basis disabilitas.

Berdasarkan hasil wawancara pada 30 Agustus 2019 dengan salah seorang anggota relawan demokrasi Kabupaten Solok basis Relasi, menyatakan animo lansia terhadap pemilu sangat bagus namun mereka mengalami kesulitan dalam mengetahui peserta caleg hal ini dikarenakan keterbatasan penglihatan dan sebagian dari lansia tidak bisa membaca/buta huruf. Selanjutnya Menur Kusumasari relawan demokrasi basis khusus menyebutkan selain masalah penglihatan dan minimnya pengetahuan lansia tentang caleg yang akan dipilih, lansia juga mengalami kesulitan membedakan surat suara yang akan digunakan saat pemilihan. Namun terdapat perbedaan respon lansia yang diungkapkan Cici Sartika relawan basis disabilitas. Lansia justru bersikap apatis bahkan lansia mengatakan tidak perlu ikut berpartisipasi dalam pemilu dan ada yang sudah menentukan pilihan siapa yang akan mereka pilih.

Sosialisasasi untuk pemilih lansia tidak kalah penting dibanding pemilih pemula. Keikutsertaan pemilih lansia dalam pemilu juga mempengaruhi tingkat partisipasi pemilih. Keterbatasan fisik dan pengetahuan yang dimiliki lansia perlu mendapatkan perhatian khusus. Sehingga, meskipun sudah lanjut usia tidak membatasi mereka untuk ikut serta dalam pemilu. Oleh karena itu, sosialisasi pemilihan umum serentak 2019 penting diberikan kepada lansia.

Berdasarkan latar belakang masalah diatas, maka dalam penulisan ini akan dibahas tentang peran relawan demokrasi dalam sosialisasi pemilih umum serentak 2019 pada pemilih lanjut usia di Kabupaten Solok. Adapun tujuan penelitian ini adalah untuk mendeskripsikan peran relawan demokrasi dalam sosialisasi pemilihan umum serentak 2019 pada pemilih lanjut usia di Kabupaten Solok, untuk mendeskripsikan kendala yang dihadapi relawan demokrasi dalam sosialisasi pemilihan umum serentak 2019 pada pemilih lanjut usia di Kabupaten Solok dan untuk mendeskripsikan upaya relawan demokrasi sosialisasi pemilihan umum serentak 2019 pada pemilih lanjut usia di Kabupaten Solok.

\section{METODE PENELITIAN}

Jenis penelitian yang digunakan adalah penelitian kualitatif dengan pendekatan deskriptif, karena dalam penelitian ini akan mendeskripsikan tentang peran relawan demokrasi dalam sosialisasi pemilu serentak 2019 pada usia lanjut usia di Kabupaten Solok. Penelitian dilakukan di KPU Kabupaten Solok dengan wilayah hukum Nagari Koto Baru Kecamatan Kubung Kabupaten Solok. Adapun informan dalam penelitian ini adalah ketua Komisi Pemilihan Umum Kabupaten Solok, kasubag teknis dan humas, staff teknis dan humas, relawan demokrasi Kabupaten Solok basis keluarga, basis perempuan, basis khusus, basis disabilitas dan basis relasi serta masyarakat Kabupaten Solok yang lanjut usia. Untuk 
Volume 1 No. 42018

memperoleh data yang cukup, maka penulis pengumpulkan data dengan cara wawancara dan studi dokumentasi.

\section{HASIL DAN PEMBAHASAN}

Peran dan Fungsi Relawan Demokrasi dalam Sosialisasi Pemilu Serentak 2019 pada Pemilih Lanjut Usia di Kabupaten Solok

Peranan adalah status atau kedudukan. Apabila seseorang melakukan hak dan kewajibannya sesuai dengan kedudukan maka dia telah menjalankan peranannya. Antara peran dan dan kedudukan tidak dapat dipisahkan dan keduanya saling berikatan (Soekarno dalam Risfandy: 2017). Teori peran sangat erat kaitannya dengan sosialisasi. Sejumlah sosiolog menyebutkan sosialisasi adalah teori mengenal peranan. Meskipun Park menjelaskan dampak masyarakat atas perilaku dalam hubungannya dengan peran. Namun jauh sebelumnya Ralph Linton, seorang antropolog telah mengembangkan teori peran. Teori peran menggambarkan interaksi sosial dalam terminologi aktor-aktor yang bermain sesuai dengan apa yang titetapkan oleh budaya. Sesuai dengan teori ini harapan-harapan peran merupakan pemahaman bersama yang menuntun kita untuk berperilaku dalam kehidupan sehari-hari.

Menurut teori ini masyarakat yang dibarengi dengan pemahaman tentang peran-peran secara otomatis akan lebih paham dalam berinteraksi dengan lingkungan sekitarnya. Karena sesuatu yang diajarkan dengan peran adalah salah satu faktor utama dalam mencapai kepuasan tersendiri bagi individu atau kelompok untuk menjalankan sebuah fungsi. Hal ini dikaitkan dengan bagaimana seorang individu atau masyarakat memahami apa yang dilakukan oleh agen sosialisasi. Oleh karena itu perlu peran yang aktif dalam proses sosialisasi atas individu ataupun kelompok masyarakat agar tercapai keinginan yang diinginkan. Zanden dalam Damsar (2012:152) mengungkapkan, sosialisasi merupakan suatu proses interaksi sosial dengan mana orang memperoleh pengetahuan, sikap, nilai dan perilaku esensial untuk partisipasi efektif dalam masyarakat.

Selanjutnya, Rush dan Althof merupakan dua orang yang memperkenalkan teori sosiologi politik melalui buku mereka yang berjudul Pengantar Sosiologi Politik. Dalam buku tersebut, Rush dan Althoft menerbitkan terminologi baru dalam menganalisis perilaku politik tingkat individu yaitu sosialisasi politik. sosialisasi politik adalah suatu proses memperkenalkan sistem politik pada seseorang dan bagaimana orang tersebut menentukan tanggapan serta reaksi-reaksi mereka terhadap gerak gejala politik (Rush dan Althoft dalam Damsar 2012:153). Menurut A. Thio (Damsar, 2012:153) sosialisasi politik adalah proses dengan mana individuindividu memperoleh pengetahuan, kepercayaan-kepercayaan dan sikap politik.

Selanjutnya Damsar (2012: 154) menyimpulkan bahwa sosialisasi politik memiliki dua poin penting yaitu berhubungan dengan proses dan tujuan. Sesuatu yang berhubungan dengan proses seperti transmisi nilainilai, pengetahuan, kepercayaankepercayaan, sikap politik dan harapan politik. Sedangkan sesuatu yang berhubungan dengan tujuan 
adalah sesuatu yang diharapkan agar mampu berpartisipasi efektif dalam aspek politik dari kehidupan masyarakat.

Kemudian Rush dan Althoff (2011: 22-23) menyebutkan sosialisasi politik adalah proses, oleh pengaruh mana seorang individu bisa mengenali sistem politik, yang kemudian menentukan sifat persepsipersepsinya mengenai politik serta reaksi-reaksinya terhadap gejala-gejala politik. Sosialisasi mencakup pemeriksaan mengenai lingkungan kultur, lingkungan politik dan lingkungan sosial dari masyarakat individu yang bersangkutan, juga mempelajari sikap-sikap politik serta penilaiannya terhadap politik. Maka sosialisasi politik merupakan mata rantai paling penting diantara sistemsistem sosial dengan sistem politik, namun satu sistem bisa berbeda sekali dengan sistem lainnya. Dilihat dari satu pandangan politik tertentu, sosialisasi politik adalah luar biasa pentingnya sebagai proses dengan mana individu-individu, sampai pada kadar yang berbeda bisa terlibat dalam satu sistem politik yaitu dalam partisipasi politik.

Dari beberapa pengertian diatas dapat diambil kesimpulan bahwa sosialisasi politik adalah suatu proses transmisi nilai-nilai dan pengetahuan politik individu atau masyarakat untuk membentuk sikap politik dalam kehidupan bermasyarakat, baik melalui pendidikan politik ataupun indoktrinasi politik. Dalam sosialisasi politik terdapat beberapa agen yang dipandang memegang peranan penting diantaranya keluarga, sekolah, teman sebaya, dan media masa. Selain keempat agen sosialisasi politik tersebut juga terdapat agen sosialisasi politik lainnya seperti partai politik dan pemerintah yang termasuk kedalam agen sosialisasi politik secondary group (Damsar, 2012:154).

\section{Relawan demokrasi sebagai \\ fasilitator pendidikan politik} diharapkan untuk menjalankan peran mereka sebagai agen pendidikan politik transformatif. Salah satu perannya adalah memfasilitasi perubahan strategi pembelajaran dari indoktrin ke strategi pembelajaran kritis, dialogis dan partisipasif. Sebagai pendidikan politik transformatif relawan demokrasi memberikan materi pendidikan politik dengan strategi yang ekslusif sesuai dengan komunitas yang ditargetkan. Pendidikan politik dibangun atas kesadaran politik komunitas dan difasilitasi oleh masyarakat itu sendiri. Materi, strategi dan media dipilih berdasarkan target komunitas.

\section{Relawan}

demokrasi mempunyai peran sebagai mitra KPU dalam menyosialisasikan tentang pemilihan umum serentak 2019 kepada masyarakat dan sebagai agen pendidikan pemilih. Dalam menjalankan perannya sebagai mitra KPU relawan demokrasi memiliki fungsi meningkatkan kualitas proses pemilu, meningkatkan partisipasi pemilih, meningkatkan kepercayaan publik terhadap proses demokrasi, membangkitkan kesukarelaan masyarakat sipil dalam agenda pemilu dan demokratisasi. Sedangkan sebagai agen pendidikan pemilih relawan demokrasi memiliki fungsi untuk menyebarkan informasi dan pengetahuan tentang pemilu serentak 2019 dan menyampaikan prosedur pelaksanaan pemilu seperti tahapan pemilu, mekanisme pemilihan dan memutakhirkan Daftar Pemilih Tetap. 
Dalam melaksanakan perannya sebagai agen pendidikan pemilih, relawan demokrasi memberikan sosialisasi kepada masyarakat sesuai dengan sasaran basisnya. Mengingat bahwa dalam basis relawan demokrasi tidak memiliki basis khusus untuk pemilih lansia bukan berarti pemilih lansia luput dari sosialisasi. Sosialisasi kepada pemilih lansia disasar melalui beberapa basis diantaranya basis keluarga, basis disabilitas, basis khusus, basis perempuan dan basis relasi.

Dari temuan lapangan juga didapat bahwa relawan demokrasi mempunyai pengaruh dalam meningkatkan partisipasi pemilih pada pemilu serentak 2019. Partisipasi pemilih tersebut terdiri dari pemilih pemula hingga pemilih lansia. Peningkatan partisipasi pemilih tidak terlepas dari peran relawan demokrasi sebagai agen pendidikan pemilih dalam sosialisasi pemilu serentak 2019. Untuk pemilih lansia itu sendiri, mereka perlu mendapatkan perhatian khusus karena suara mereka juga tidak kalah pentingnya dengan pemilihpemilih lainnya. Jadi perlu juga dibentuk basis khusus untuk pemilih lansia. Karena keikutsertaan pemilih lansia dalam pemilu juga mempengaruhi tingkat partisipasi pemilih dalam pemilu serentak 2019.

Partisipasi pemilih pada pemilu serentak 2019 di Kabupaten Solok memperlihatkan peningkatan dari partisipasi pemilih pada pemilu 2014 yaitu 74,42\% dari 70\%. Meskipun partisipasi pemilih memperlihatkan angka peningkatan namun persentasi tersebut masih terbilang rendah. Karena belum mencapai terget nasional yang telah ditetapkan KPU yaitu 77,5\%. Kemudian dari hasil penelitian juga didapatkan bahwa pemilih lansia saat memiliki animo yang lebih tinggi dibanding pemilihpemilih lainnya. Mereka bersemangat mengikuti sosialisasi, malahan yang banyak datang saat sosialisasi adalah lansia.

\section{Kendala Yang Dihadapi Relawan Demokrasi dalam Sosialisasi Pemilu Serentak 2019 pada Pemilih Lanjut Usia di Kabupaten Solok}

Kendala yang dihadapi relawan demokrasi dalam sosialisasi pemilihan umum serentak 2019 berbeda-beda sesuai dengan situasi dan kondisi lingkungan yang dihadapi saat sosialisasi dari masing-masing basis. Walaupun ada diantara mereka yang merasa tidak ada kendala sama sekali saat melakukan sosialisasi kepada masyarakat. Menurut Hariadi dalam Rafni (2016), menyimpulkan bahwa belum maksimalnya kinerja relawan demokrasi terkait dengan mekanisme kerja yang digunakan dalam setiap komunitas disamping pola pikir masyarakat yang sebagian besar belum memiliki kesadaran mengenai pentingnya pendidikan demorasi.

Kemudian selaras dengan itu Widyastuti dalam Rafni (2016) mengatakan bahwa salah satu masalah dalam relawan demokrasi adalah latar belakang relawan demokrasi yang tidak mewakili berbagai segmen/basis yang akan menjadi sasaran dan praktek pelaksanaan relawan demokrasi menjadi kurang jelas serta tidak terstrukturnya programprogram pelatihan yang dijalankan. Selanjutnya salah satu penyebab belum tercapainya tujuan dari gerakan relawan demokrasi adalah proses pelatihan yang diberikan secara 
singkat dengan materi yang terbatas serta persyaratan pendidikan relawan demokrasi dalam petunjuk pelaksanaannya yang hanya tamatan Sekolah Menengah Atas.

Berdasarkan hasil penelitian, peneliti mengelompokkan kendala yang datang dari internal dan eksternal:

a) Kendala yang datang dari internal

Relawan demokrasi dalam menjalankan tugasnya memiliki masa kerja selama 3 bulan, yang dimulai dari persiapan, pelatihan dan pelaksanaan sosialisasi yang dilakukan oleh relawan demokrasi. Waktu tersebut dirasa tidak optimal oleh beberapa basis relawan demokrasi karena dalam waktu tersebut ada beberapa sasaran yang belum sempat mereka berikan sosialisasi seperti basis berkebutuhan khusus yang memiliki sasaran ke lapas tetapi karena terkendala waktu mereka tidak sempat kesana untuk memberikan sosialisasi.

Walaupun jumlah relawan demokrasi ini sudah ditentukan dalam pedoman pelaksanaan program relawan demokrasi yaitu jumlah relawan demokrasi maksimalnya 55 (lima puluh lima) orang yang mewakili keseluruhan basis pemiih dengan ketetuan stiap basis pemilih terdiri dari minimal 4 (empat) orang relawan. Dalam hal tertentu tidak dapat diwakili kurang dari 4 (empat) orang relawan untuk setiap basis pemilih, dapat digantikan atau ditambahkan ke basis pemilih lain yang merupakan mayoritas perwakilan pemilih disana. Oleh karena itu komposisi jumlah relawan untuk mewakili setiap basis pemilih jumlahnya berbeda-beda disesuaikan dengan kebutuhan di setiap KPU Kabupaten/Kota. Para relawan berharap jumlah relawan untuk masa yang akan datang ditambah.

b) Kendala yang datang dari eksternal

Tidak semua lansia memiliki fisik yang masih sehat, beberapa diantaranya sudah memiliki keterbatasan fisik Keterbatasan fisik pada lansia merupakan faktor usia. Keterbatasan fisik tersebut berupa keterbatasan pendengaran, dan penglihatan. Bahkan ada diantara lansia tersebut yang tidak bisa membaca/buta huruf. Masyarakat mengalami krisis kepercayaan terhadap calon pemimpin atau kepada para caleg disebabkan oleh trauma terhadap sikap peserta pemilu, yang mana peserta pemilu semasa kampanye sering datang ke daerah mereka dengan mengumbar janji-janji namun setelah terpilih mereka tidak pernah lagi datang ke daerah mereka. Salah satu dampak yang dapat dilihat adalah ketika relawan demokrasi datang untuk memberikan sosialisasi tentang pemilu serentak 2019 ada masyarakat yang menggap relawan demokrasi adalah orang dari partai untuk melakukan kampanye. Sehingga mereka awalnya tidak bersikap ramah, namun setelah diberikan penjelasan baru mereka paham dan menerima.

\section{Upaya Relawan Demokrasi Sosialisasi Pemilu Serentak 2019 Pada Pemilih Lanjut Usia di Kabupaten Solok}

Pendidikan politik atau pendidikan pemilih merupakan upaya yang disengaja dan sistematis untuk membentik individu agar mampu menjadi partisipasi yang bertanggung jawab secara etis dalam mencapai 
tujuan-tujuan politik. Pendidikan politik diharapkan mampu mempengaruhi individu agar ia memperoleh informasi lebih lengkap, wawasan lebih jernih, keterampilan politik yang handal sehingga ia mampu memainkan peran politik yang cerdas, mampu bersikap dan bertindak sesuai dengan etika politik kebanyakan. Oleh sebab itu, menurut Rafni (2016), hadirnya relawan demokrasi yang bertugas sebagai agen pendidikan politik transformatif dapat merubah pembelajaran pendidikan politik itu sendiri dari yang bersifat indoktrinasif ke pola-pola pendidikan dialogis, kritis, kreatif dan partisipatif.

\section{Adapun upaya relawan} demokrasi dalam mengatasi masalah masa kerja yang singkat yaitu selama 3 (bulan) dari bulan Februari sampai bulan April 2019 dan keterbatasan jumlah anggota relawan demokrasi. Jumlah setiap basis berbeda ada yang berjumlah 4 (empat) orang, ada yang berjumlah 5 (lima) orang dan ada yang berjumlah 6 (enam) orang. Untuk basis keluaraga terdiri dari 5 (lima) orang, basis penyandangg disabilitas terdiri dari 4 (empat orang), basis berkebutuhan khusus terdiri dari 4 (empat) orang, basis perempuan terdiri dari 6 (enam) orang dan basis relasi terdiri dari 5 (lima) orang. Karena hal tersebut dalam pelaksanaan sosialisasi para relawan demokrasi ini juga saling bantu dan bekerja sama dengan basis lain.

Di sisi eksternal, berdasarkan Peraturan Menteri Kesehatan Republik Indonesia Nomor 25 Tahun 2016 Tentang Rencana Aksi Nasional Kesehatan Lanjut Usia Tahun 20162019, lanjut usia adalah seseorang yang telah mencapai usia 60 tahun keatas.
Mereka yang sudah berumur di atas 60 tahun masih mempunyai hak atas suaranya. Keikutsertaan mereka dalam pemilu tidak kalah pentingnya dengan pemilih pemula. Untuk itu relawan demokrasi berupaya menyampaikan betapa pentingnya keterlibatan lansia dalam menyukseskan pemilihan umum. Agar hak suara mereka dapat digunakan dengan baik dan benar saat di TPS maka berdasarkan hasil penelitian untuk mengatasi keterbatas fisik yang dimiliki lansia tersebut dalam sosialisasi relawan demokrasi harus menyampaikan informasi dengan mengulang-ngulang kembali memberikan pemahaman dengan memperlihatkan contoh surat suara, mereka harus mengenali gambar partai dan nomor urut peserta pemilu serta relawan demokrasi juga harus menyampaikan secara individu.

Kemudian adapun upaya relawan demokrasi dalam mengatasi sebagian masyarakat yang mengalami krisis kepercayaan terhadap calon pemimpin adalah memberikan pendidikan politik kepada masyarakat untuk selalu selektif dalam menggunakan hak pilihnya serta memberikan himbauan kepada lansia supaya tidak mudah terpengaruh oleh pihak-pihak tertentu yang ingin mengambil keuntungan atau melakukan kecurangan dalam pemilu.

\section{KESIMPULAN}

Peran relawan demokrasi ada dua yaitu sebagai mitra KPU fungsinya untuk meningkatkan kualitas proses pemilu, meningkatkan partisipasi pemilih, meningkatkan kepercayaan publik terhadap proses demokrasi, dan membangkitkan kesukarelaan masyarakat sipil dalam 
agenda pemilu dan demokratisasi dan sebagai agen pendidikan pemilih fungsinya untuk menyebarkan informasi dan pengetahuan tentang pemilu serentak 2019 menyampaikan prosedur pelaksanaan pemilu seperti tahapan pemilu, mekanisme pemilihan dan memutakhirkan Daftar Pemilih Tetap. Adapun kendala yang dihadapi relawan demokrasi adalah waktu persiapan dan pelatihan dan pelaksanaan yang sangat singkat dan keterbatasan jumlah anggota relawan demokrasi dan keterbatasan fisik dari lansia serta sebagian masyarakat mengalami krisis kepercayaan terhadap calon pemimpin.

Upaya relawan demokrasi dalam mengatasi kendala tersebut adalah saling bekerjasama dengan basis-basis lain, menyampaikan informasi dan pengetahuan tentang pemilu dengan berulang kali dan menyampaikan secara individu. Kemudian memberikan pendidikan politik kepada masyarakat untuk selalu selektif dalam menggunakan hak pilihnya serta memberikan himbauan kepada lansia supaya tidak mudah terpengaruh oleh pihak-pihak tertentu yang ingin mengambil keuntungan atau melakukan kecurangan dalam pemilu.

\section{DAFTAR PUSTAKA}

Adelia, Hendra Saputra, Sakdon, T. K. 2019. Peran Badan Pengawas Pemilu Dalam Meningkatkan Partisipasi Lansia Pada Pemilu 2019 Di Kota Pangkalpinang. Jurnal Ilmiah Mahasiswa Volume 1 Nomor 1 April 2019 Fakultas Ilmu Sosial Dan Ilmu Politik Universitas Bangka Belitung, 1(April), 83-95.
Damsar. 2012. Pengantar Sosiologi Politik. Jakarta: Kencana.

Febriantanto, P., Yogyakarta, U. M., \& Demokrasi, R. 2018. Implementasi Kebijakan Program Relawan Demokrasi Pada Pemilu 2014 di KPU Kota Yogyakarta, 18(2).

Hariyanto, K., dan Rafni, A. 2019. Implementasi Kebijakan Program Relawan Demokrasi oleh KPU Kota Padang pada Pilkada 2018. Journal of Civic Education, 2(3), 190-196.

Purbolaksono, A. (2019), Mei 31. Meningkatnya Partisipasi Pemilih dalam Pemilu 2019. Retrieved November 19, 19. From The Indonesian Institute Center For Public Policy Research:

https://www.theindonesianinstitute.c om/meningkatnya-partisipasipemilih-dalam-pemilu-2019/.

Rafni, A., \& Suryanef, S. (2017). Roles of Democratic Volunteers in Developing Political Literacy. Mimbar: Jurnal Sosial dan Pembangunan, 33(1), 74-80.

Rafni, A., \& Suryanef, S. (2016). Relawan Demokrasi dan Pendidikan Politik Transformatif. Laboratorium Sosiologi, FISIP UNAND. Jilid 2. Halaman 1068-1082.

Risfandy. (2017). Tingkat Efektivitas Sosialisasi Komisi Independen Pemilih Kota Banda Aceh Dalam Pemilihan Kepala Daerah Periode 2017-2022 (Studi Penelitian Terhadap Etnis Tionghoa Di PEunayong Kota Banda Aceh). Jurnal Ilmiah Mahasiswa FISIP Unsyiah Volume 2, Nomor 3: 1-21 Agustus 2017, 2, 1-21 
Rush, M dan Althoff, P. 2011.

Pengantar Sosiologi Politik. Rajawali Pers: Jakarta.

Sucipto, Dri. 2019. Partisipasi Pemilih Pada Pemilihan Umum (Studi Di Komisi Pemilihan Umum Kab . Banggai Laut). Yustisiabel, Jurnal Hukum, Fakultas Hukum, Universitas Muhammadiyah Sucipto 